\title{
CRTE LIČNOSTI I AFEKTIVNA ULOGA OMILJENIH I NEOMILJENIH NASTAVNIKA
}

\author{
Milica Tošić Radev ${ }^{1}$ \\ Univerzitet u Nišu, Filozofski fakultet, Departman za psihologiju \\ Ana Pešikan \\ Univerzitet u Beogradu, Filozofski fakultet, Departman za psihologiju
}

\begin{abstract}
Apstrakt: Cilj istraživanja je bio ispitati da li se omiljeni i neomiljeni nastavnici razlikuju u pogledu vlastite umešnosti u afektivnoj ulozi, da li postoji povezanost kompetentnosti u afektivnom domenu sa crtama ličnosti nastavnika, kao i da li je moguće izdvojiti diskriminativnu funkciju koja razlikuje omiljene i neomiljene nastavnike na temelju njihove strukture ličnosti. Inventarom ličnosti Neo PI-R operacionalizovana je struktura ličnosti po pet učenicima izrazito omiljenih i neomiljenih nastavnika. Njihovu kompetentnost $u$ afektivnom domenu procenilo je 200 učenika sedmog razreda na Upitniku za evaluaciju afektivne uloge nastavnika. Rezultati su pokazali da se omiljeni i neomiljeni nastavnici mogu jasno prepoznati na osnovu izraženosti sledećih crta ličnosti: vulnerabilnost, popustljivost, depresivnost, vrednost, osećaj dužnosti i socijalna nelagodnost. Od crta ličnosti, u predikciji učeničke procene nastavnika najznačajnija je crta depresivnosti koja objašnjava čak $60 \%$ varijanse ukupnog skora nastavnika na Upitniku za evaluaciju afektivne uloge nastavnika. Iako na malom uzorku, rezultati su značajni i upućuju na zaključak da je umešnost nastavnika u afektivnoj interakciji sa učenicima povezana sa karakteristikama ličnosti nastavnika koja se verovatno reflektuje na njihovo ponašanje i odnos prema učenicima što za posledicu ima dobre ili loše odnose sa učenicima. Rezultati su diskutovani u smeru potrebe da se podizanjem svesti nastavnika o ovoj profesionalnoj ulozi i mogućnostima da se dodatnim edukacijama poboljša kvalitet njihovog rada.
\end{abstract}

Ključne reči: afektivna uloga nastavnika, omiljeni i neomiljeni nastavnici, crte ličnosti.

\section{Uvod}

Obrazovanje predstavlja jedan složeni sistem sa jasnom organizacijom. Nastavnik u tom sistemu ima svoj položaj iz koga proističe i njegova uloga. Svaka društvena uloga predstavlja sistem očekivanog ponašanja koji se vezuje za položaj

\footnotetext{
${ }^{1}$ milica.tosic.radev@filfak.ni.ac.rs
} 
pojedinca u nekoj društvenoj grupi (Rot, 1994) i obuhvata aktivnosti koje se smatraju obaveznim, aktivnosti na koje osoba na nekom položaju u grupi ima pravo i očekivani način psihološkog reagovanja, ali uloga i zabranjuje određena ponašanja (Havelka, 2000).

U proučavanju nastavničkih uloga mogu se uočiti različiti pristupi. Zajednička karakteristika većine radova koji se bave nastavničkim ulogama jeste to da autori pokušavaju da ih nekako klasifikuju, ali se razlikuju kriterijumi klasifikacije, pa time i broj uloga koje identifikuju različiti autori (Pešikan, 2020). Uloga nastavnika zavisi od koncepcije nastave, zadataka koji se posledično stavljaju pred nastavnika, kao i od utvrđenih obrazovno-vaspitnih ciljeva. Svaka od koncepcija nastave drugačije vidi prirodu školskog učenja, a samim tim i ulogu nastavnika u tom procesu. U tradicionalnoj, frontalnoj, dominantno predavačkoj nastavi najznačajnija mu je uloga prenosioca znanja - nastavnik je onaj koji prezentuje znanje koje učenici treba da usvoje, a prateće su ocenjivanje naučenoga i sprovođenje discipline. Savremena nastava je orijentisana na učenje, okrenuta je kreiranju situacija učenja. Njeni ciljevi podrazumevaju izgradnju kompleksnijih obrazovnih postignuća (Blum, 1981), kognitivnih kompetencija, ali i veština u afektivnoj, socijalnoj i psiho-motornoj sferi. U ovako koncipiranoj nastavi uloga nastavnika se bitno menja. On je medijator u procesu saznavanja, kreira aktivnosti učenja u zoni narednog razvitka učenika, stručnjak koji vešto i kompetentno koristi prilike za kreiranje povoljne sredine za učenje prilagođeno potrebama svojih učenika. Takođe, nastavnik utiče na odnos učenika prema sredini za učenje, a stilom svog komuniciranja sa učenicima i na njihovo školsko postignuće i celoviti razvoj ličnosti (intelektualni, socijalni, moralni, emocionalni i fizički razvoj) (Pešikan, 2020). U takvoj koncepciji nastave nastavnik ima brojne i složene uloge.

Za potrebe ovog rada korišćena je klasifikacija nastavničkih uloga Ivića i saradnica (Ivić i sar., 2003), koja se temelji na principima aktivnog učenja (Ivić i sar., 2003). Imajući u vidu zahteve koje principi aktivnog učenja/nastave stavljaju pred nastavnika, izdvajaju se sledeće uloge: 1) nastavnička uloga u užem smislu; 2) motivaciona uloga; 3) evaluativna uloga; 4) saznajno-dijagnostička uloga; 5) uloga regulatora socijalnih odnosa u razredu kao grupi i 6) uloga partnera u afektivnoj interakciji. Najdetaljnije je razrađena nastavnička uloga u užem smislu-njegova uloga kao predavača, voditelja i organizatora nastave i partnera u pedagoškoj komunikaciji. Motivaciona uloga podrazumeva napore nastavnika da podstakne učenike na učenje i rad, da razvija, podstiče i održava radoznalost i njihova interesovanja za intelektualni rad i razvija radne navike kod učenika. Saznajno-dijagnostička uloga odnosi se na procesnu dijagnostiku, šta i koliko učenik zna i može, na koji način misli, radi i uči, šta su mu preferencije i interesovanja i slično. Kao evaluator, nastavnik kontinuirano prati rad i razvoj i istovremeno procenjuje proces učenja i ocenjuje postignuće učenika. Ova uloga obuhvata formativno i sumativno ocenjivanje, sve vrste intervencija koje daju povratnu informaciju o uspešnosti procesa učenja, o učeničkom ponašanju i njegovoj ličnosti. Nastavnik bi trebalo da bude i neko ko prati, reguliše socijalne odnose u grupi i podstiče konstruktivnu komunikaciju među učenicima uspostavljanjem discipline, rešavanjem konflikata, oblikovanjem 
uzajamnih odnosa sa učenicima i između učenika, itd. Kada je reč o afektivnoj ulozi nastavnika, navodi se da nastavnik kao partner u afektivnoj komunikaciji mora da prepoznaje potrebe i afektivna stanja svojih učenika i način kako da adekvatno reaguje na njih i da im svojim ponašanjem pomogne u konstruktivnom nošenju sa njima. Nastavnik mora da bude vešt u dijagnostifikovanju psihičkih stanja učenika, uključujući i potencijalne teškoće sa kojima se učenik suočava i da pomaže razgovarajući sa učenikom, porodicom, stručnim licima, upućujući učenika, kada je to potrebno, na određeni tretman i slično (Ivić i sar., 2003).

Afektivna uloga se uobičajeno vezuje za pomaganje detetu koje ima probleme, ali u procesu nastave/učenja ona obuhvata mnogo više od toga. U detaljnijoj konceptualizaciji i operacionalizaciji ove nastavničke uloge izdvojene su njene brojne važne komponente, kao što su: motivisanost za rad sa decom i mladima, raspoloživost nastavnika učenicima, učeničko poverenje u nastavnika, poznavanje učenika i nastavnikova spremost da sarađuje sa kolegama povodom određenog učenika, osetljivost na potrebe i afektivna stanja učenika, empatija i adekvatno reagovanje na reakcije učenika, modelovanje pozitivne socioemocionalne klime, itd. (Tošić Radev, 2016).

Nalazi istraživanja o kvalitetima dobrih i omiljenih nastavnika pokazuju da su afektivni atributi, iako često zanemareni zbog svoje teško merljive prirode, vrlo važan aspekt kompetencija nastavnika i da moraju biti uzeti u obzir ako želimo pravilno da odredimo efektivnost nastavnika (Goldhaber \& Anthony, 2004). Reč je o kvalitetima koji se fokusiraju na pozitivne lične osobine nastavnika, neophodne za efektivnu nastavu. Briga, poštovanje, motivacija, istrajnost, entuzijazam i predanost su sve primeri teško uhvatljivih svojstava ličnosti nastavnika koji su proučavani (Brown et al., 2008; Goldhaber, 2002; Goodwin, 2010). Miler (1987) je izdvojio samo neke od afektivnih obeležja nastavnika poput: pozitivnih odnosa sa učenicima, mentalnog zdravlja nastavnika i brojnih ponašanja kojima nastavnik pokazuje interesovanje za učenike kroz entuzijazam, ohrabrenje, humor i dostupnost), smatrajući ih važnim determinantama efektivnosti nastavnika. Drugi autori na temelju učeničkih odgovora izdvajaju četiri dimenzije dobre nastave: briga za učenike; razumevanje učenika, zabava i ljubav (Thomas \& Montomery, 1998). Pored ovih učenici kao poželjne karakteristike dobrih i omiljenih nastavnika izdvajaju: poštovanje tuđeg mišljenja, iskrenost, nepristrasnost, poštovanje učenika, razumevanje problema učenika i zainteresovanost za njih, spremnost da pomognu, prijateljsku nastrojenost, veselost, toplinu, druželjubivost, ljubaznost, prilagodljivost, pravednost, moralnost, doslednost, toleranciju, samokontrolu, razumevanje i strpljenje, tj. sposobnost da se obrati pažnja na učenika, sposobnost da se uspostave dobri odnosi sa učenicima i roditeljima, toplina, saradljivost, otvorenost mišljenja, različita interesovanja, dopuštanje veće autonomije učenika uz održavanje reda (Bjekić, 1999; Blishen, 1969; Odom, 1943; Rubio, 2009; UNICEF, 2001).

Iako se u novije vreme sve više govori emocijama u procesu obrazovanja (Elias. 2001; Hargreaves, 1994; Nias, 1996; Pianta, 1997; Tošić Radev \& Pešikan, $2017 \mathrm{a}, \mathrm{b})$ i o profesionalnom razvoju nastavnika, tj. razvoju osobe unutar njene profesionalne uloge, njegova afektivna uloga ostaje zanemarena. U koncepciji 
profesionalnog razvoja nastavnika nastavnik je profesionalac, a profesionalizam karakterišu (profesionalna) autonomija i odgovornost (Ivić i sar., 2003). Ono što je stručno i naučno nedopustivo, jeste procenivanje kvaliteta i uspešnosti nastavnika preko ispitivanja njegove ličnosti (Stojiljković, 2012) i kapaciteta za obavljanje različitih uloga. Drugim rečima, prećutno se prihvata da način na koji nastavnici reaguju na različite socijalne situacije proizilazi iz individualnih razlika između nastavnika u pogledu ličnosti, stila ili drugih ličnih svojstava (Mills, 2003, Stronge, 2002, Wentzel, 2002), da to, dakle, nije deo profesije, profesionalne uloge već urođenih karakteristika ili talenta. Između ostalog i adekvatan odnos nastavnika prema učenicima u praksi se prećutno prihvata kao vrlina pojedinih nastavnika, a u vezi sa njihovim ličnim interesima, motivacijom i ličnosti (Ackerman \& Heggestad, 1997). Ukratko, u današnjoj obrazovnoj politici, brižnost se posmatra kao izbor koji je napravljen od strane pojedinih nastavnika u skladu sa njihovom filozofijom i vlastitim odabranim profesionalnim ciljevima (O'Connor, 2008). Time se, pored ostalog, ozbiljno ugrožava profesionalizacija uloge nastavnika.

U skladu sa iznetim nalazima, predmet ovog istraživanja je ispitivanje da li se omiljeni i neomiljeni nastavnici razlikuju u pogledu vlastite umešnosti u afektivnoj nastavničkoj ulozi, da li postoji povezanost kompetentnosti u afektivnoj ulozi sa crtama ličnosti nastavnika, kao i da li je moguće izdvojiti diskriminativnu funkciju koja razlikuje omiljene i neomiljene nastavnike na temelju njihove strukture ličnosti.

\section{Metodologija}

\section{Uzorak i postupak istraživanja}

Predstavljeno istraživanje i prateći rezultati deo su obuhvatnije studije o afektivnoj ulozi nastavnika ${ }^{2}$ i njenih determinušućih faktora. Uzorak istraživanja činili su nastavnici i 200 učenika sedmog razreda iz ukupno 6 odeljenja tri gradske osnovne škole. Prvo je utvrđen „status“ nastavnika prema percepciji učenika. U istraživanje su uključeni, iz svake škole, samo nastavnici koji su predstavljali ekstreme, tj. oni koji su označeni od strane učenika kao najomiljeniji (pet) ili kao najmanje omiljeni (pet).

Postupak se sastojao u tome što je istraživač pre početka istraživanja u saradnji sa psihologom i/ili direktorom škole obišao jedno odeljenje sedmog razreda i zamolio učenike da na papiru napišu imena i prezimena po dva svoja omiljena i neomiljena nastavnika. Nakon analize učeničkih odgovora istraživač je izabrao nastavnike prema sledećem kriterijumu: izabrani su nastavnici koji su najčešće navođeni kao omiljeni, a da se pri tome nisu nijednom našli na listi neomiljenih i obrnuto, nastavnici koji su se najčešće našli na listi neomiljenih, a da se nijednom nisu našli na listi omiljenih. Ovaj postupak je ponovljen u tri osnovne škole na teritoriji Niša, kako bi se iz svake škole obuhvatili samo nedvosmisleno omiljeni i neomiljeni nastavnici.

\footnotetext{
${ }^{2}$ Doktorske disertacije „Afektivna uloga nastavnika: Konceptualizacija i empirijska provera konstrukta“ (Tošić-Radev, 2016).
} 
Nakon upoznavanja sa nastavnikom, on je obavešten da je afektivni odnos između nastavnika i učenika predmet istraživanja, da je istraživanje anonimno i dobrovoljno i zamoljeni su da popune test ličnosti i omoguće istraživaču da na jednom času zada upitnik učenicima.

\section{Instrumenti istraživanja}

U istraživanju su korišćeni sledeći instrumenti:

- Inventar ličnosti (NEO Personal Inventory - Revised, forma S), standardizovan na našoj populaciji (Đurić Jočić i sar., 2004) namenjen je merenju izraženosti sledećih dimenzija i crta ličnosti odraslih osoba: neuroticizama (i užih aspekata: anksioznosti, hostilnosti, depresivnosti, socijalne nelagodnosti, impulsivnosti i vulnerabilnosti); ekstraverzije (topline, druželjubivosti, asertivnosti, aktiviteta, potrage za uzbuđenjem i pozitivne emocije); otvorenosti (fantazije, estetike, osećanja, akcije, ideja i vrednosti); saradljivosti (poverenja, iskrenosti, altruizma, popustljivosti, skromnosti i blage naravi); i savesnosti (kompetencije, reda, dužnosti, postignuća, samodiscipline i promišljenosti). Rezultat na inventaru ličnosti NEO PI-R pruža informaciju o izraženosti dimenzija i crta ličnosti pojedinca definisanih u skladu sa petofaktorskim modelom strukture ličnosti. Svaka skala namenjena merenju određenog domena obuhvata po šest subskala namenjenih merenju užih aspekata, crta sa po osam ajtema, što ukupno čini 240 ajtema. Na svakoj stavci ispitanik izražava stepen svog slaganja ili neslaganja sa sadržajem stavke na petostepenoj skali procene. Na normativnom uzorku u Srbiji (Đurić Jočić i sar., 2004; Knežević i sar., 2004) provera pouzdanosti Inventara na uzorku u Srbiji (Knežević i sar., 2004) ukazuje na visoku pouzdanost skala koje ispituju pet domena (Cronbach alfa u rasponu od 0,80 do 0,90).

- Upitnik za evaluaciju afektivne uloge nastavnika - forma za učenike (AfUN- U, Tošić Radev, 2016) sačinjen je od 27 stavki na kojima učenici izražavaju stepen slaganja na petostepenoj skali procene. Tvrdnje predstavljaju operacionalizaciju različitih komponenti afektivne uloge nastavnika (npr. „Moj nastavnik me sluša kada mu se obratim“; „Moj nastavnik je $u$ više navrata pokazivao interesovanje za mene i moj život, moju porodicu, interesovanja i uspeh van škole"). Instrument ima jednofaktorsku strukturu i visok nivo pouzdanosti (Cronbach alfa 0.96).

\section{Rezultati}

Kada je reč o kompetentnosti nastavnika u realizaciji afektivne uloge, rezultati pokazuju da empirijski raspon skorova odstupa od teorijskog raspona skorova, kao $i$ da se u potpunosti razlikuju empirijski raspon skorova omiljenih i neomiljenih nastavnika (Tabela 1$)$. 
Tabela 1. Teorijski i empirijski raspon skorova nastavnika na upitniku AfUN-U i prosečna učenička procena o kompetentnosti nastavnika u afektivnoj ulozi

\begin{tabular}{|c|c|c|c|c|c|c|}
\hline \multirow[t]{2}{*}{ AfUN-Up } & \multicolumn{2}{|c|}{$\begin{array}{l}\text { Teorijski raspon } \\
\text { skorova }\end{array}$} & \multicolumn{2}{|c|}{$\begin{array}{l}\text { Empirijski raspon } \\
\text { skorova }\end{array}$} & \multicolumn{2}{|c|}{ Prosečna izraženost } \\
\hline & Min & Max & Min & Max & $A S$ & $S D$ \\
\hline Nastavnik & & & 35 & 88 & 63,67 & 23,54 \\
\hline Omiljeni nastavnici & 27 & 135 & 79 & 88 & 84,71 & 4,14 \\
\hline Neomiljeni nastavnici & & & 35 & 61 & 42,62 & 11,07 \\
\hline
\end{tabular}

Posebno je važno uočiti da nema nastavnika, čak ni među omiljenim nastavnicima, koje su učenici ocenili najvišim ocenama u pogledu uspešnosti u njihovoj ulozi u afektivnom domenu, dok neomiljeni nastavnici postižu izuzetno niske skorove pri učeničkoj proceni njihove umešnosti u afektivnoj interakciji sa učenicima.

Primenom t-testa, dalja analiza pokazuje da su razlike između omiljenih i neomiljenih nastavnika u pogledu afektivne interakcije sa učenicima statistički značajne i na ovako malom uzorku nastavnika (Tabela 2).

Tabela 2. Razlike u učeničkoj proceni omiljenih i neomiljenih nastavnika na Upitniku za procenu afektivne uloge nastavnika AfUN-U

\begin{tabular}{cccccccc}
\hline Upitnik & \multicolumn{2}{c}{ Omiljeni nastavnici } & \multicolumn{2}{c}{$\begin{array}{c}\text { Neomiljeni } \\
\text { nastavnici }\end{array}$} & t & df & Sig. \\
\hline & AS & SD & AS & SD & & & \\
AfUN-U & $\mathbf{8 4 , 7 1}$ & 4,15 & $\mathbf{4 2 , 6 2}$ & 11,07 & $-7,959$ & 8 &, 000 \\
\hline
\end{tabular}

Na prvi pogled ovakav nalaz može izgledati donekle cirkularno, budući da su učenici na upitniku za procenu afektivne uloge nastavnika različito procenili svoje omiljene i neomiljene nastavnike, koje su prethodno sami odabrali. Međutim, upitnik AfUN-U se sastoji od pitanja koja predstavljaju operacionalizaciju prethodno utvrđenih dimenzija afektivne uloge nastavnika (npr. bliskost $u$ odnosu nastavnika i učenika, dostupnost nastavnika, nastavnička briga o okruženju učenika itd.). Budući da je upitnik sastavljen od selekcionisanih pitanja, tako da predstavljaju operacionalizaciju poduloga nastavnika u afektivnom domenu, dobijeni podatak nosi u sebi novu i važnu informaciju da razlike u nastavničkoj kompetentnosti u domenu afektivne uloge vode do jasnih razlika u učeničkoj percepciji nastavničkog ponašanja, tj. toga da li će oni učenicima biti omiljeni ili neomiljeni.

Drugo istraživačko pitanje odnosilo se na povezanost nastavničkog skora na upitniku AfUN - U i dimenzija i crta ličnosti nastavnika. U tabeli 3 prikazani su rezultati prosečne izraženosti osobina i dimenzija ličnosti ispitanih nastavnika dobijenih postupcima deskriptivne statistike. 
Tabela 3. Izraženost bazičnih dimenzija i crta ličnosti kod nastavnika

\begin{tabular}{|c|c|c|c|c|c|c|}
\hline \multirow{2}{*}{ Naziv domena } & \multicolumn{2}{|c|}{ Omiljen nastavnik } & \multicolumn{2}{|c|}{ Neomiljen nastavnik } & \multicolumn{2}{|c|}{ Nastavnik } \\
\hline & $\mathrm{M}$ & SD & $\mathrm{M}$ & SD & $\mathrm{M}$ & SD \\
\hline Anksioznost & 15,4 & 1,96 & 20,20 & 2,76 & 17,80 & 5,65 \\
\hline Hostilnost & 11,60 & 2,96 & 14,60 & 1,69 & 13,10 & 5,32 \\
\hline Depresivnost & 10,20 & 2,01 & 16,80 & 1,77 & 13,50 & 5,3 \\
\hline Socijalna nelagodnost & 14,00 & 1,45 & 17,00 & 1,26 & 15,5 & 3,27 \\
\hline Impulsivnost & 16,40 & 1,54 & 16,60 & 1,50 & 16,50 & 3,21 \\
\hline Vulnerabilnost & 20,20 & 1,98 & 19,00 & 2,14 & 19,60 & 4,40 \\
\hline Neuroticizam & 87,80 & 10,25 & 104,20 & 5,83 & 96 & 19,58 \\
\hline Toplina & 28,00 & 1,09 & 25,20 &, 86 & 26,6 & 2,55 \\
\hline Druželjubivost & 28,40 & 3,40 & 26,00 & 2,02 & 27,20 & 6,03 \\
\hline Asertivnost & 20,80 & 3,01 & 19,00 & 2,19 & 19,90 & 5,63 \\
\hline Aktivitet & 24,80 & 1,46 & 22,20 & 1,59 & 23,50 & 3,50 \\
\hline Potraga za uzbuđenjima & 14,00 & 1,09 & 14,60 & 2,56 & 14,3 & 4,16 \\
\hline Pozitivne emocije & 25,60 & 3,47 & 22,40 & 2,09 & 24 & 6,27 \\
\hline Ekstraverzija & 141,60 & 10,57 & 129,40 & 6,55 & 135,5 & 19,61 \\
\hline Fantazija & 26,00 & 2,66 & 25,00 & 1,92 & 25,5 & 4,93 \\
\hline Estetika & 27,00 & 4,21 & 28,20 & 2,13 & 27,6 & 7,06 \\
\hline Osećanja & 30,40 & 2,11 & 26,60 & 1,66 & 28,5 & 4,48 \\
\hline Akcija & 24,00 & 1,64 & 22,20 &, 86 & 23,1 & 2,92 \\
\hline Ideje & 27,40 & ,93 & 22,80 & 1,58 & 25,1 & 3,28 \\
\hline Vrednosti & 20,80 & 1,11 & 21,60 &, 40 & 21,2 & 1,81 \\
\hline Otvorenost & 155,60 & 6,27 & 146,40 & 5,56 & 151 & 13,4 \\
\hline Poverenje & 31,20 & 2,48 & 26,20 & 1,43 & 28,7 & 5,01 \\
\hline Iskrenost & 36,40 & 1,03 & 34,00 & 2,51 & 35,2 & 4,24 \\
\hline Altruizam & 31,00 & 2,00 & 30,40 & 1,44 & 30,7 & 3,68 \\
\hline Popustljivost & 29,80 & 2,78 & 28,60 & 1,63 & 29,2 & 4,85 \\
\hline Skromnost & 25,40 & 2,54 & 24,60 & 1,81 & 25 & 4,67 \\
\hline Blaga narav & 26,40 & 1,21 & 22,40 & 1,17 & 24,4 & 3,27 \\
\hline Saradljivost & 180,20 & 7,04 & 166,20 & 4,85 & 173,2 & 14,73 \\
\hline Kompetentnost & 29,00 & 1,94 & 30,00 & 1,81 & 29,7 & 3,97 \\
\hline Red & 26,20 & 1,62 & 28,60 & 1,29 & 27,4 & 3,34 \\
\hline Osećaj dužnosti & 30,80 & 1,28 & 30,80 & ,97 & 30,80 & 2,39 \\
\hline
\end{tabular}




\begin{tabular}{ccccccc} 
Postignuće & 27,80 & 1,32 & 27,40 & 1,21 & 27,6 & 2,67 \\
Samodisciplina & 34,20 & 1,39 & 34,60 & 1,75 & 34,4 & 3,34 \\
Promišljenost & 29,20 & 2,39 & 28,20 & 1,68 & 28,7 & 4,4 \\
Savesnost & $\mathbf{1 7 7 , 6 0}$ & $\mathbf{7 , 4 2}$ & $\mathbf{1 7 9 , 6 0}$ & $\mathbf{5 , 2 0}$ & $\mathbf{1 7 8 , 6}$ & $\mathbf{1 3 , 5 6}$ \\
\hline
\end{tabular}

$\mathrm{Na}$ ispitanom uzorku nastavnika, na većini dimenzija i crta ličnosti mere su znatno više u odnosu na normativni uzorak iz Srbije koje su prilikom validacije instrumenta dali Knežević i saradnici (2004). Razlike u odnosu na norme su prilično više na svim skalama, izuzev Neuroticizma. Ovi rezultati su saglasni sa već postojećim nalazima, dobijenim na većim uzorcima, o većoj izraženosti dimenzija ekstraverzije, otvorenosti za iskustvo, saradljivosti i savesnosti kod nastavnika (Đigić, 2013). Viši skorovi nastavnika na navedenim dimenzijama su očekivani, s obzirom da se radi o pripadnicima profesije u kojoj su neophodne navedene osobine, jer uključuju visokoobrazovane pojedince koji se brinu o vaspitanju i obrazovanju dece. Po svojoj prirodi ili profesionalnoj orijentaciji moglo se i očekivati da će nastavnici biti društvene osobe, otvorene prema svetu i novinama, saradljivi i savesni.

Proverom povezanosti ličnosnih karakteristika nastavnika i učeničke procene njihovih kompetencija u afektivnoj ulozi dobijene su statistički značajne i visoke korelacije.

Tabela 4. Povezanost učeničke procene nastavnika na upitniku AfUN-U i samoprocene osobina ličnosti nastavnika na inventaru Neo PI-R

\begin{tabular}{lc}
\hline NEO PI - R & AfUN - Up \\
\hline Depresivnost(N3) &,$- 803^{* *}$ \\
Toplina (E1) &, $699^{*}$ \\
Ideje (O5) &, $744^{*}$ \\
Blaga narav (A6) &, $626^{*}$ \\
\hline
\end{tabular}

Legenda. $* *-p<, 005 ; *-p<, 050$

Kao što se vidi u Tabeli 4, kao adekvatne u afektivnoj ulozi učenici doživljavaju one nastavnike koji su osobe blage naravi, tople, otvorene za nove ideje i nisu sklone doživljavanju negativnih emocija.

Štaviše, postupkom stepeničaste regresione analize, dobijeno je da se već samo crtama ličnosti iz domena Neuroticizma može objasniti $60 \%$ varijanse skora koje nastavnik dobija pri učeničkoj proceni njegove kompetentnosti u afektivnom domenu. Pritom, kao jedini značajan prediktor nastavnikove umešnosti u afektivnoj ulozi izdvojena je crta depresivnost nastavnika (Tabela 5). 
Tabela 5. Predikcija skora nastavnika na upitniku AfUN crtama ličnosti iz domena neuroticizma

\begin{tabular}{lccccccc}
\hline & $\mathrm{R}$ & $\mathrm{R}$ square & $\begin{array}{c}\text { Adjusted R } \\
\text { square }\end{array}$ & $\mathrm{F}$ & Sig (F) & Beta & Sig \\
\hline $\begin{array}{l}\text { Model 1 } \\
\begin{array}{l}\text { Prediktor - Depresivnost } \\
\text { Kriterijum: AfUN-U) }\end{array}\end{array}$ &, 803 &, 645 &, 601 & 14,54 &, 005 &,- 803 &, 000 \\
\hline
\end{tabular}

Na kraju, u želji da izdvojimo crte ličnosti po kojima bi se eventualno mogli razlikovati omiljeni $i$ neomiljeni nastavnici primenili smo postupak stepeničaste kanoničke diskriminativne analize.

Tabela 6. Hi-kvadrat test diskriminacione funkcije

\begin{tabular}{cccccccc}
\hline F-ja & $\begin{array}{c}\text { Svojstvena } \\
\text { vrednost }\end{array}$ & \% varijanse & $\begin{array}{c}\text { Kanonička } \\
\text { korelacija }\end{array}$ & $\begin{array}{c}\text { Wilksova } \\
\text { lambda }\end{array}$ & Hi kvadrat & df & p \\
\hline 1 & 1403,28 & 100 & 1,000 &, 001 & 32,613 & 7 &, 000 \\
\hline
\end{tabular}

Diskriminativnom analizom izdvojili smo jednu funkciju koja dobro diskriminiše nastavnike što se može videti u tabeli 6 . Kanonička korelacija izdvojene funkcije sa varijablom omiljeni/neomiljeni nastavnici iznosi 1,000; $<<.000$. U Tabeli 7 prikazana je struktura kanoničke funkcije, u Tabeli 8 prikazani su standardizovani koeficijenti kanoničke funkcije, a u Tabeli 9 centroidi grupa za datu diskriminativnu funkciju.

Tabela 7. Matrica strukture kanoničke funkcije

\begin{tabular}{cc}
\hline Crte & Diskriminaciona funkcija \\
\hline Vulnerabilnost &,- 522 \\
Popustljivost &,- 493 \\
Depresivnost &,- 334 \\
Vrednosti &,- 324 \\
Dužnost &, 318 \\
Socijalna nelagodnost &,- 309 \\
\hline
\end{tabular}

Tabela 8. Standardizovani koeficijenti kanoničke funkcije

\begin{tabular}{cc}
\hline Crte & $\begin{array}{c}\text { Standardizovani } \\
\text { koeficijenti }\end{array}$ \\
\hline Anksioznost & $-15,938$ \\
Impulsivnost & 26,459 \\
Toplina & 17,283
\end{tabular}




\begin{tabular}{cc} 
Druželjubivost & $-8,646$ \\
Pozitivne emocije & $-8,073$ \\
Fantazija & 3,985 \\
Ideje & 19,836 \\
\hline
\end{tabular}

Tabela 9. Centroidi grupa za I diskriminativnu funkciju

\begin{tabular}{lc}
\hline Omiljenost nastavnika & Funkcija I \\
\hline Neomiljen & $-33,506$ \\
Omiljen & 33,506 \\
\hline
\end{tabular}

Posmatrano iz ugla izdvojene diskriminativne funkcije možemo videti da se omiljeni i neomiljeni nastavnici mogu međusobno dobro razlikovati na osnovu sledećih crta ličnosti: vulnerabilnosti, popustljivosti, depresivnosti, vrednosti, osećaja dužnosti i socijalne nelagodnosti. Drugim rečima, omiljeni nastavnici su manje osetljivi i ranjivi u stresnim situacijama, nisu skloni doživljavanju negativnih emocija, poseduju dobre socijalne veštine i nisu preterano popustljivi niti skloni preispitivanju usvojenih vrednosti dok se čvrsto, ali ne previše rigidno drže svojih principa.

Posebno je interesantan nalaz da se datim modelom predikcije, na temelju crta ličnosti, diskriminativnom funkcijom postiže stopostotna diskriminacija omiljenih i neomiljenih nastavnika (Tabela 10).

Tabela 10. Rezultat klasifikacije

\begin{tabular}{|c|c|c|c|c|c|}
\hline \multicolumn{3}{|c|}{ Omiljenost nastavnika } & \multicolumn{2}{|c|}{ Predikcija pripadnosti grupi } & \multirow[t]{2}{*}{ Total } \\
\hline \multirow{5}{*}{ Original } & & & Neomiljen & Omiljen & \\
\hline & Broj & Neomiljen & 5 & 0 & 5 \\
\hline & & Omiljen & 0 & 5 & 5 \\
\hline & $\%$ & Neomiljen & $100 \%$ & 0 & $100 \%$ \\
\hline & & Omiljen & 0 & $100 \%$ & $100 \%$ \\
\hline \multirow{4}{*}{ Cross-validated } & Broj & Neomiljen & 5 & 0 & 5 \\
\hline & & Omiljen & 0 & 5 & 5 \\
\hline & $\%$ & Neomiljen & $100 \%$ & 0 & $100 \%$ \\
\hline & & Omiljen & 0 & $100 \%$ & $100 \%$ \\
\hline
\end{tabular}




\section{Diskusija}

Istraživanje je imalo za cilj da proveri da li je kompetentnost nastavnika u afektivnoj interakciji sa učenicima povezana sa njihovim individualnim ličnim svojstvima i sa doživljajem učenika o tome da li im je nastavnik omiljen ili ne. Rezultati ukazuju da učenici registruju određena ponašanja nastavnika iz afektivnog domena, kao što su toplina u odnosu sa učenicima, brižnost, dostupnost učenicima, kvalitet komunikacije i pravičnost u odnosu sa učenicima, a učenička kategorizacija nastavnika na omiljene i neomiljene se potpuno poklapa sa učeničkom procenom nastavnika na upitniku AfUN - U. Ovakvi nalazi jasno govore o važnosti podizanja svesti nastavnika o ovom aspektu njegove profesije, posebno ukoliko imamo na umu koliko pozitivne relacije nastavnik-učenik zavise od afektivnih atributa nastavnika (Bjekić, 1999; Blishen, 1969; Odom, 1943; Rubio, 2009; UNICEF, 2001) i koliko je povezan sa pozitivnim stavovima učenika prema školi (e.g. Arbeau, et al., 2010; Birch \& Ladd, 1997), kognitivnim postignućima i disciplinom, kao i socioemocionalnim razvojem i blagostanjem i motivacijom (Buyse et al., 2011; Gest et al., 2005; Graziano et al., 2007; Murray \& Greenberg, 2001; Valiente et al., 2008). Naravno, rezultati sugerišu da nije reč samo o ličnom uvidu i unapređenju svesti nastavnika već da je neophodno o ovim crtama voditi računa u profesionalnom razvoju nastavnika.

Nastavnička umešnost $u$ afektivnoj interakciji sa učenicima povezana je sa njihovom strukturom ličnosti koja se verovatno reflektuje na njihovo ponašanje, odnos prema učenicima, pa i prema profesiji uopšte i ima za posledicu pozitivne ili negativne odnose sa učenicima. Bolju učeničku procenu u pogledu kompetentnosti u afektivnoj nastavničkoj ulozi postižu nastavnici koji su osobe blage naravi, topli, otvoreni ka idejama i nisu skloni ka doživljavanju negativnih emocija. Nastavnici blaže naravi, pa i brižniji, saosećajniji i ljubazniji u svom odnosu sa učenicima su veštiji u afektivnoj interakciji u učionici. Oni su, takođe, otvoreniji za nove ideje, što verovatno dovodi do toga da češce unose novine u svoj način rada, spremniji su da stiču i primenjuju nova znanja, tehnike i metode rada i otvoreni su prema sugestijama i inicijativama učenika. Istraživanja pokazuju da kvalitet odnosa nastavnik-učenici i opšta atmosfera u nastavi/učenju utiče i na kvalitet i ishode obrazovanja (Cornelius - White, 2007; Hamre \& Pianta, 2001; Pianta \& Nimetz, 1991; Roorda et al., 2011; Sabol \& Pianta, 2012).

S druge strane, izražena depresivnost, koja se može ispoljiti na različite načine u ponašanju nastavnika, pre svega kroz stalno nezadovoljstvo i neadekvatna ponašanja, pomeranje negativnih emocija na učenike, nezainteresovanost za posao ili na brojne druge načine izdvojena je kao najznačajniji prediktor. Ovaj prediktor zajedno sa drugim crtama ličnosti iz domena Neuroticizma, objašnjava više od polovine skora koji nastavnici dobijaju od strane učenika. Depresivnost, kao crta ličnosti emocionalno nestabilnih osoba, podrazumeva značajno smanjenje, ili potpuno povlačenje emotivnih ulaganja osobe u socijalnu okolinu, a i u sebe, pa ne iznenađuje rezultat da je upravo ova crta ličnosti najviše povezana sa (ne)umešnošću nastavnika u afektivnoj komunikaciji s učenicima. U nedavnoj longitudinalnoj 
studiji (Lifshin et al., 2020) ispitivan je odnos nastavnika iz ugla teorije afektivne vezanosti i dobijen je sličan nalaz. Naime, nesigurna afektivna vezanost samog nastavnika doprinela je smanjenju učeničkog prilagođavanja tokom školske godine. Pritom, negativan model drugih kod nastavnika, tj. njegovo izbegavanje bliskosti imalo je najsnažniji efekat na svu decu, čak i na onu koja su bila sigurno vezana za majku. Ipak ovaj efekat je zavisio od toga u kojoj meri učenik doživljava nastavnika kao nesenzitivnog i nereagujućeg. Slično depresivnosti, u školskom kontekstu, izbegavajućem nastavniku fali osnovni resurs koji je deci neophodan za prilagođavanje - toplina, dostupnost i responzivnost. Izbegavanje je povezano sa nedostatkom prosocijalnih osećanja i tendencija u ponašanju i odlikuje ga deficit $u$ brižnosti prema drugima što kod učenika izaziva osećaj odbačenosti, nevoljenosti i usamljenosti (Lifshin et al., 2020).

Pored ovih nalaza, rezultati diskriminativne analize pokazuju da se na osnovu crta ličnosti nastavnika može izdvojiti model predikcije koji gotovo bez greške diskriminiše nastavnike u omiljene ili neomiljene. Naime, učenici za svoje omiljene nastavnike biraju one koji nisu vulnerabilni i ranjivi u stresnim situacijama, nisu skloni doživljavanju negativnih emocija, one koji poseduju dobre socijalne veštine, ali nisu preterano popustljivi, niti skloni preispitivanju usvojenih vrednosti, dok se dovoljno, ali ne previše rigidno drže svojih principa.

Rezultati sugerišu da nastavnici, svesno ili nesvesno, ispoljavaju svoju ličnost u svom radu i odnosu prema poslu i učenicima i da je, dalje, ličnost nastavnika povezana sa učeničkim doživljajem i kvalitetom odnosa koji uspostavljaju sa nastavnikom. Ovo je značajan nalaz koji govori o tome da se na osnovu samoprocene ličnosti nastavnika, sa velikom verovatnoćom, može tačno odrediti da li će nastavnik učenicima biti omiljen ili neomiljen, uz bitno ograničenje da je naš model nestabilan zbog malog uzorka i većeg broja prediktora u modelu, te bi svakako navedene nalaze trebalo proveriti na većem uzorku. Takođe, rezultati potvrđuju nagoveštaje drugih autora da odnosi nastavnika sa učenicima, nažalost, prilično zavise od ličnih i individualnih atributa nastavnika (Mills, 2003, Stronge, 2002, Wentzel, 2002).

Ograničenje ove studije predstavlja mali uzorak nastavnika, no, dovoljan za dobijanje uvida o odnosima crta ličnosti i ponašanja nastavnika Takođe, nalazi ovog istraživanja dobijaju na značaju nakon iskustva sa školovanjem dece i mladih u vreme pandemije COVID-19 virusa i nalaza da učenicima veoma nedostaju vršnjaci i nastavnici, da drugačija, siromašnija socioafektivna komunikacija u nastavi/ učenju daje povećan broj mentalnih problema dece i mladih, osećaj usamljenosti, izolovanosti, prepuštenosti sebi i slično (Anderson, 2021). Ovi podaci su dodatna potvrda važnosti afektivne uloge nastavnika i otvaraju novo istraživačko pitanje (i polje) da li se u onlajn okolnostima može realizovati u punoj meri afekivna uloga nastavnika i kako? 


\section{Zaključak}

Rezultati ovog istraživanja potvrđuju da određene osobine ličnosti karakterišu učenicima omiljene i neomiljene nastavnike. Dalje, omiljeni nastavnici imaju poželjne osobine ličnosti i uspešnije realizuju svoju profesionalnu ulogu u afektivnom domenu. Za neomiljene nastavnike, naravno, važi suprotno. Neomiljeni nastavnici u svom poslu i odnosu prema učenicima nisu svesni svoje uloge kao partnera $u$ afektivnoj komunikaciji sa učenicima i u odnosu sa decom postupaju spontano, u skladu sa strukturom svoje ličnosti, koju karakteriše sklonost doživljavanju negativnih osećanja, manjak otvorenosti i previše rigidnosti, što se negativno odražava na kvalitet nastave/učenja.

Izgleda da su različita ponašanja nastavnika vezana za njegovu ulogu u afektivnom domenu u velikoj meri određena ličnošću nastavnika i na taj način nedovoljno shvaćena kao deo očekivanih ponašanja nastavnika u okviru njegove profesionalne uloge (ni stjuardesa se ne smeška putnicima zato što joj se dopadaju već što je to deo njene profesionalne uloge, stvaranja poverenja i dobre atmosfere). Naši nalazi, međutim, ne znače da dimenzije i crte ličnosti pojedinca treba da budu kriterijumi pri selekciji nastavnika, niti da je dobar nastavnik predodređen strukturom ličnosti i da se obrazovanjem ne može ništa učiniti. Naprotiv, ovakvi podaci nam samo govore o tome koje su dimenzije i crte ličnosti karakteristične za nastavnike koji sa učenicima uspostavljaju kvalitetan odnos i koji ispunjavaju svoju ulogu partnera u afektivnoj komunikaciji. Time se ne isključuje mogućnost da se uticajem na podizanje nivoa svesti i pedagoške kulture nastavnika dodatno poboljša kvalitet rada svih nastavnika. Čak suprotno, istraživanje upravo naglašava važnost i potrebu da se nastavnici planski obučavaju svojim profesionalnim ulogama, posebno ulozi partnera u afektivnoj komunikaciji sa učenicima.

Ovo je posebno važno, jer nalazi pokazuju da neki nastavnici nisu svesni svoje afektivne uloge $\mathrm{i}$ da bi se njenim uvođenjem u obuku i evaluaciju rada nastavnika izbegla mogućnost da se nastavnici u nastavi ponašaju spontano, na temelju ličnih osobina, umesto na osnovu profesionalnih znanja, umenja i razvijene svesti o vlastitim profesionalnim ulogama. Pritom, ovu ideju potkrepljuju nalazi istraživanja koja se bave evaluacijom programa koji su usmereni na razvoj i usavršavanje veština emocionalne inteligencije nastavnika, emocionalne pismenosti, emocionalne podrške i drugih sposobnosti nastavnika relevantnih za kompetentnost $\mathrm{u}$ afektivnom domenu.

Svi ovi nalazi sugerišu da se ove nastavničke kompetencije mogu vežbati i da nastavnici i svi oni koji se pripremaju za nastavnički poziv, mogu imati značajne koristi od programa koji se fokusiraju na socioemocionalne kompetencije. Sve ovo znači, a brojni nalazi koji se bave odnosom nastavnik-učenik to i potvrđuju, da je od ključnog značaja da važnost interakcije nastavnik-učenik bude prepoznata $i$ naglašena u profesionalnom razvoju nastavnika i u svim fazama i aspektima njegovog rada. Emocije nisu nešto što sme da bude odvojeno od pripremnih aktivnosti za nastavničku profesiju, niti ignorisano u samoj učionici, jer nastavnici ne mogu biti efikasni ukoliko ignorišu emocionalnu stranu procesa nastave i učenja. 


\section{Literatura}

Ackerman, P. L. \& Heggestad, E. D. (1997). Intelligence, personality, and interests: Evidence for overlapping traits. Psychological Bulletin, 121(2), 219-245.

Anderson, L. W. (in press). Schoolong interrupted: Educating children and youth in the Covid-19 era. Center for Educational Policy Studies Journal, 11.

Arbeau, K. A., Coplan, R. J. \& Weeks, M. (2010). Shyness, teacher-child relationships, and socio-emotional adjustment in grade 1. International Journal of Behavioral Development, 34(3), 259-269.

Birch, S. H. \& Ladd, G. W. (1997). The teacher-child relationship and children's early school adiustment. Journal of School Psychology, 35(1), 61-79.

Bjekić, D. (1999). Profesionalni razvoj nastavnika. Užice: Učiteljski fakultet.

Blishen, E. (1969). The school that I'd like. London: Penguin.

Blum, B.S. (1981). Taksonomija ili klasifikacija obrazovnih i odgojnih ciljeva. Beograd: Republički zavod za unapređivanje vaspitanja i obrazovanja.

Brown, N., Morehead, P. \& Smith, J. B. (2008). But I love children: Changing elementary teacher candidates' conceptions of the qualities of effective teachers. Teacher Education Quarterly, 35(1), 169-183.

Buyse, E., Verschueren, K. \& Doumen, S. (2011). Preschoolers' attachment to mother and risk for adjustment problems in kindergarten: can teachers make a difference? Social Development, 20(1), 33-50.

Cornelius-White, J. (2007): Learner-Centered Teacher-Student Relationships Are Effective: A Meta-Analysis, Review of Educational Research, 77(1),113-145.

Đigić, G. (2013). Ličnost nastavnika i stilovi upravljanja razredom. Doktorska disertacija. Niš: Filozofski fakultet.

Đurić-Jočić, D., Džamonja-Ignjatović, T., Knežević, G. (2004). NEO PI-R primena $i$ interpretacija. Beograd: Centar za primenjenu psihologiju Društva psihologa Srbije.

Elias, M. J. (2001). Preparing children for the tests of life, not a life of tests. Education Week, 21(4), 40.

Gest, S. D.,Welsh, J. A. \& Domitrovich, C. E. (2005). Behavioral predictors of changes in social relatedness and liking school in elementary school. Journal of School Psychology, 43(4), 281-301.

Goldhaber, D. \& Anthony, E. (2007). Can teacher quality be effectively assessed? National board certification as a signal of effective teaching. The Review of Economics and Statistics, 89(1), 134-150.

Goldhaber, D. (2002). Mystery of good teaching: The evidence shows that good teachers make a clear difference in student achievement. the problem is that we don't really know what makes a good teacher.(feature). Education Next (Feature), 1(1), 50-55.

Goodwin, B. (2010). Good teachers may not fit the mold. Educational Leadership, 68(4), $79-80$

Graziano, P. A., Reavis, R. D., Keane, S. P. \& Calkins, S. D. (2007). The role of emotion regulation in children's early academic success. Journal of School Psychology, 45(1), 3-19. 
Hamre, B. K. \& Pianta, R. C. (2001). Early teacher-child relationships and the trajectory of children's school outcomes through eighth grade. Child Development, 72(2), 625638.

Hargreaves, A. (1994). Changing teachers, changing times: Teachers'work and culture in the postmodern age. London: Cassell.

Havelka, N. (2000). Učenik $i$ nastavnik u obrazovnom procesu. Beograd: Zavod za udžbenike i nastavna sredstva.

Ivić, I., Pešikan, A., Antić, S. (2003). Aktivno učenje 2. Beograd: Institut za psihologiju.

Katz, Y. J., Kontoyianni, A., Lang, P., Menezes, S. N., Romi, S., Vasileiou, L., et al. (2003). North and south contrasted: Cultural similarities and differences in affective education. In A. C. Torres \& A. Anti- karmen (Eds.), The International Handbook on the Sociology of Education (pp. 360-380). Lanham, MD: Rowman and Littlefield.

Knežević, G., Džamonja-Ignjatović, T., Đurić-Jočić, D. (2004). Petofaktorski model ličnosti. Beograd: Centar za primenjenu psihologiju Društva psihologa Srbije.

Lifshin, U., Kleinerman, I. B., Shaver, P. R., \& Mikulincer, M. (2020). Teachers' attachment orientations and children's school adjustment: Evidence from a longitudinal study of first graders. Journal of Social and Personal Relationships, 37(2), 559-580.

Miller, P. (1987). Ten characteristics of a good teacher. English Teaching Forum, 25(1), 40-41.

Mills, C. J. (2003). Characteristics of effective teachers of gifted students: Teacher background and personality styles of students. Gifted Child Quarterly, 47(4), 272 281.

Murray, C., \& Greenberg, M. T. (2001). Relationships with teachers and bonds with school: social emotional adjustment correlates for children with and without disabilities. Psychology in the Schools, 38(1), 25-41.

Nias, J. (1996). Thinking about feeling: The emotions in teaching. Cambridge Journal of Education, 26(3), 293-306.

O’Connor, K.E. (2008). „You choose to care“: Teachers, emotions and professional identity. Teaching and Teacher Education 24(1), 117-126.

Odom, C.L. (1943). An Objective Determination of the Qualities of a Good College Teacher Peabody Journal of Education, 21(2), 109-116.

Pešikan, A. (2020). Učenje u obrazovnom kontekstu. Beograd: Službeni glasnik.

Pianta, R. C. (1997). Adult-child relationship processes and early schooling. Early Education and Development, 8(1), 11-26.

Roorda, D. L., Koomen, H. M. Y., Spilt, J. L. \& Oort, F. J. (2011). The Influence of Affective Teacher-Student Relationships on Students' School Engagementand Achievement: A Meta-Analytic Approach. Review of Educational Research, 81(4), 493-529.

Rot, N. (1994). Osnovi socijalne psihologije. Beograd: Zavod za udžbenike i nastavna sredstva.

Rubio, M. C. (2009). "Effective teachers -Professional and personal skills", en ENSAYOS, Revista de la Facultad de Educación de Albacete, № 24. Preuzeto 5.8. 2014. godine sa http://dialnet.unirioja.es/descarga/articulo/3282843.pdf 
Sabol, T. J., \& Pianta, R. C. (2012). Recent trends in research on teacher-child relationships. Attachment \& Human Development, 14(3), 213-231.

Stojiljković, S. (2012). Psihološke karakteristike nastavnika. Niš: Filozofski fakultet.

Stronge, J.H. (2002). Qualities of effective teachers. Alexandria, VA: Association for Supervision and Curriculum Development

Thomas, J. A. \& Montgomery, P. (1998). On becoming a good teacher: Reflective practice with regard to children's voices. Journal of Teacher Education, 49(5), 372-380.

Tošić Radev, M. (2016). Afektivna uloga nastavnika: Konceptualizacija i empirijska provera konstrukta. Doktorska disertacija. Filozofski fakultet Beograd.

Tošić Radev, M., Pešikan, A. (2017a). „Komadić koji nedostaje“ u procesu obrazovanja: socioemocionalno učenje. Nastava i vaspitanje, LXVI(1), 37-54.

Tošić Radev, M., \& Pešikan, A. (2017b). Emocije u školi: smetnja ili podrška učenju? Zbornik Instituta za pedagoška istraživanja, 49(2), 261-278.

UNICEF. (2001). Primary education in the Federal Republic of Yugoslavia - analysis and recommendations. Belgrade: UNICEF, Belgrade Office.

Valiente, C., Lemery-Chalfant, K., Swanson, J. \& Reiser, M. (2008). Prediction of children's academic competence from their effortful control, relationships, and classroom participation. Journal of Educational Psychology, 100(1), 67-77.

Wentzel, K. R. (2002). Are effective teachers like good parents? Teaching styles and student adjustment in early adolescence. Child Development, 73(1), 287-301.

\title{
PERSONALITY TRAITS AND AFFECTIVE ROLE OF FAVORITE AND UNFAVORITE TEACHERS
}

\author{
Milica Tošić Radev \\ University of Nis, Faculty of Philosophy, Department of Psychology
}

Ana Pešikan

University of Belgrade, Faculty of Philosophy, Department of Psychology

\begin{abstract}
The purpose of this research was to examine whether the most and least favorite teachers differ in their skills related with affective role in teaching; whether there is a relationship between teacher's competence in the affective domain and his personality traits and whether it is possible to discriminate the most and least favorite teachers based on their personality traits. NEO Personal InventoryRevised was used to operationalize the personality traits of five students' most and five least favorite teachers. Their competence in the affective domain was assessed by 200 seventh-grade students on The student questionnaire for the evaluation of the affective role of the teacher. The results showed that the most and the least favorite teachers can be discriminated based on their: vulnerability, compliance, depression, values, dutifulness, and social anxiety. Of the personality traits, in the prediction of the students' assessment of the teacher, the depression explained even $60 \%$ of the
\end{abstract}


variance of the total teacher's score on the questionnaire for students' evaluation of teacher's competence in the affective role. Although obtained on a small sample, the results are significant and suggest that teacher's skills in affective interaction with students are related to his personality traits which are easily reflected in their behaviour finally resulting in good or bad relationships with students. The results were discussed in the direction of the need to increase the awareness of teachers about one of their professional roles and the possibilities to improve the quality of work of all teachers through additional education.

Keywords: affective role of the teacher, the most and the least favorite teachers, personality traits.

\section{Citiranje članka:}

Tošić Radev, M. i Pešikan, A. (2021). Crte ličnosti i afektivna uloga omiljenih i neomiljenih nastavnika. Godišnjak za pedagogiju, 6(2), 53-69. 